\title{
Research on the Forest Resource Assets Appraisal and off-office Audit
}

\author{
Huishui Su \\ Research Center of Finance and Accounting in Fujian Jiangxia University, Fujian Social Science Research Base \\ Fuzhou, Fujian Province, 350108
}

\begin{abstract}
In order to implement the construction of ecological civilization, leading cadres off-office audit of natural resource assets comes into being. The forest resource assets appraisal and off-office audit, acting as an important part of natural resource assets, are important areas for conducting leading cadres off-office audit of natural resources. Based on the forest resource assets appraisal, this work first put forward principles of forest assets appraisal, account setting and appraisal methods, then constructed a complete set of evaluation index system of off-office audit and forest resource assets appraisal, and finally proposed corresponding countermeasures for problems existing in current forest resource assets appraisal and off-office audit. This research enriched assets appraisal theory of forest resources and provided guidance for the implementation of off-office audit practice for leading cadres.
\end{abstract}

Keywords-Natural resource assets; Forest resource assets; Asset appraisal; Evaluation index system of off-office audit

\section{INTRODUCTION}

Since the reform and opening up, China has exchanged economic growth with extensive economic growth, resulting in excessive consumption, pollution and many other issues of natural resources, which have seriously affected people's daily lives. Faced with declining natural resources and constant pollution of ecological environment, the Communique of the Third Plenary Session of the 13th Central Committee of the CPC proposed to "compile balance sheet of natural resources, conduct natural resource off-office audit for leading cadres, and establish life-long accountability for ecological environmental damage system". This is a new field of audit work, and it is also a unique audit content in China. In September 2015, the State Council promulgated the Overall Plan for the Reform of Ecological Civilization System, which proposed to "explore to compile the evaluation index system of natural resources assets off-office audit of leading cadres", 1 and carried out pilot projects for the off-office audit of natural resources assets throughout China. In July 2016, the Asset Appraisal Law of the People's Republic of China deliberated and approved by the Standing Committee of the Twelfth National People's Congress provided a theoretical basis for the

\footnotetext{
Funded by: The Modernization of National Governance, Economic Power, Performance Audit (JAS180566), Social Science Planning Project of Fujian Ministry of Education; Research on the Performance Audit of Natural Resources (2014B002) and Research on Forest Assets Assessment (18KXYS01-15), the scientific training project of Fujian Jiangxia University for youth talents.

1 Excerpted from the Overall Plan for the Reform of Ecological Civilization System
}

appraisal of natural resources assets. In October 2017, the report of the 19th National Congress of the Communist Party of China proposed to "establish a state-owned natural resources asset management and natural ecological supervision institution". In April 2019, the State Council issued the Guiding Opinions on Coordinating the Reform of the Property Right System of Natural Resources Assets, which stated to" establish a natural resource asset accounting evaluation system, conduct physical quantity statistics, explore value accounting and compile balance sheets of the natural resource". ${ }^{2}$ At present, the academic community has a mature understanding of the research on the off-office audit of natural resource assets and has carried out pilot work in practice, but there is still a lack of scientific audit appraisal indicators and appraisal methods that are in line with China's actual conditions. The theory and practice remain at the exploration phase.

Therefore, this work intended to start with the forest resource assets appraisal and off-office audit, so as to put forward principles of forest assets appraisal, account setting, appraisal methods and the index system of forest assets appraisal and off-office audit, to further enrich the theory of forest resource assets appraisal, and to provide guidance for the implementation of the off-office audit practice of leading cadres.

\section{FOREST RESOURCE ASSETS APPRAISAL}

Assets appraisal of forest resources is also called assets valuation of forest resources, which is the basis for correctly understanding and evaluating the value of the assets of forest resources. Assets appraisal of forest resources plays a fundamental role in conducting assets off-office audit of forest resources.

\section{A. Principles of forest resource assets appraisal}

The Guiding Opinions on Coordinating the Reform of the Property Right System of Natural Resources Assets proposes to "develop a unified investigation and monitoring evaluation for natural resources, establish an assets appraisal system for natural resources, conduct physical statistics, explore value accounting, and compile balance sheets for natural resources". This work combined various appraisal methods proposed by the theoretical and practical circles and proposed the following principles that should be followed in the appraisal of the assets of forest resources.

\footnotetext{
2 Excerpted from the Guiding Opinions on Coordinating the Reform of the Property Right System of Natural Resources Assets
} 
First, it is necessary to follow the principle of carrying out physical accounting before value accounting. There are many kinds of forest resource assets, which are regional and difficult to comprehensively count. For the scientific, rigorous and operable appraisal, the endowment of forest resources should be respected by highlighting characteristics of the region and varieties, and the physical accounting should be carried out before value accounting. The physical quantity accounting is to take physical quantity statistics on the survey data of forest resource assets, and to reflect the savings, usage and balance of forest assets in the form of accounts. The value quantity accounting is based on the physical quantity and appraises different varieties and types of forest resource assets reasonably. Reflecting the value of forest resource assets in the form of money can realize the value of forest resources.

Second, it is necessary to follow the principle of appraising tangible assets before intangible assets. Forest resource assets include both tangible and intangible asset forms. Among them, tangible assets refer to the material data created by forest resources in the process of providing physical activities, such as young forests, middle-aged forests and mature forests. Their value can be values based on the physical quantity of forest resources. Intangible assets refer to the ecological service functional assets of forest resources, that is, the assets playing an ecological service function for human survival and development. This value is mainly reflected in the service function of ecologically sustainable development and bringing comfort experience to human life. It always converts tangible forest resource assets into ecological service value through using specific evaluation systems, which can be appraised by survey method or non-use value method.

Third, it is necessary to follow the principle of appraising stock assets before flowing assets. The stock accounting of forest resource assets refers to the amount of forest resource assets stock in a certain area at a specific time, reflecting the static distribution of forest resource assets at a specific time. The flow accounting of forest resource assets refers to the quantity and quality changes of forest resource assets in a certain area during a specific period, reflecting the dynamic distribution of forest resource assets during a certain period of time. The stock accounting is to calculate the stock of forest resource assets and to understand the distribution of forest resources from young forests to mature forests in the region, while the flow accounting is to calculate the changes of forest resource assets at the end of the period from the beginning of the period and to understand the liabilities of forest resources in the region. The two transform and complement each other.

\section{B. Accounts setting of forest resource assets appraisal}

1) Asset account setting of forest resource assets appraisal

Forest resources are extremely complex and involve a wide range of fields. There is no final conclusion on how to define forest resource assets. The Encyclopedia of China defines the narrow meaning of forest resources as forest plants whose main body is an arbor, and the broad meaning as biocenosis that has biological structure and location types and forms a specific ecological environment, consisting of woody plants as well as animals, plants and microorganisms that depend on the forest. ${ }^{3}$ According to this definition, Wei Yuanzhu et al. (2001) believed that forest resource assets refer to forest resources owned or controlled by forestry enterprises and institutions, which can be measured by currency and can generate economic benefits [1]; Mi Mingfu et al. (2018) took Guangdong as an example and state-owned forest farms as the accounting object, defining it as follows: In the forest ecosystem where the state-owned forest farm is located, the scarce natural resources that are expected to produce economic or ecological benefits are forest resource assets [2]; Bai Lianyu (2015) defined it as follows: Under the current social and economic background and technical level, forest resources owned or controlled by operating entities are formed by past transactions or events [3]. By summarizing researches of predecessors and considering reality, this work believed that defining the widely recognized concept of forest resource assets should emphasize the particularity of forest resource assets. From the perspective of economics and accounting, forest resource assets could exist in the form of tangible or intangible assets and be calculated by currency, and it could be confirmed by recording, measuring and auditing and bring economic benefits.

Based on this, in order to better calculate the forest resource assets, Forestry Sector Standard of the People's Republic of China sets the forest resources to account as woodland resource account, timber resource account and forest ecological service function account. The woodland resource account is used to calculate woodland assets of forest resource assets, mainly including level 2 items such as timber woodland, economic woodland and shelter woodland. Among them, timber woodland refers to the woodland areas that mainly plant wood or bamboo; the economic woodland refers to the woodland areas that mainly produce fruit, edible oil, seasoning, industrial raw materials and medicinal materials; shelter woodland refers to the woodland areas that are planted for maintaining soil and water, preventing wind and sand, conserving water sources and regulating climate [4]. The timber resource account is used to calculate timber assets of forest resource assets, mainly including level 2 items such as artificial forests and natural forests. Among them, artificial forests refer to forests that are constructed and cultivated by methods and techniques such as artificial seeding, planting or cutting; natural forest refers to forests that are formed naturally or promoted by human. ${ }^{4}$ The forest ecological service function account is used to calculate its forest ecosystem service functions, including water conservation, soil conservation, carbon fixation and oxygen release, air purification and biodiversity protection. ${ }^{5}$

2) Liability account setting of forest resource assets appraisal

There is currently no consensus on the research of forest resource liabilities. Huang Rongbing (2014) defined forest resource liabilities as the cost to be borne, which is to be sustained in order to maintain sustainable development, to

\footnotetext{
3 Excerpted from Encyclopedia of China

4 Excerpted from China Forestry Statistical Yearbook

5 Excerpted from Specifications for Assessment of Forest Ecosystem Services In China of Forestry Sector Standard of the People's Republic of China
} 
manage ecosystems or to restore forest resources [5]; Wang Xiaoxiao (2017) proposed that forest resource liabilities refer to the economic responsibilities undertaken when taking measures such as management and due to excessive logging, using and destructing during a certain period of time [6]. Mi Mingfu (2018) defined forest resource liabilities as of the practical responsibility, which is to be borne to maintain the sustainable development of forest resources and to maintain a balanced between supply and demand of forest resources [7].

Based on the above analysis, the liability account of forest resources reflects the degree of environmental damage and excessive consumption of resources by economic activities. In reality, it is very difficult to calculate the cost of restoring forestry resources and ecosystems to their original levels. Therefore, when constructing the balance sheets of forest resources, it is recommended to directly use the funds for repairing or restoring forest resources and their ecosystems as the liability item, that is, to divide the level 1 items of forest resource liabilities into resource liability and environmental liability. "Resource liability" is subsumed by "recovery expenditure due to over-quota logging and deforestation", "recovery expenditure due to natural disasters" and "liability expenditure for other resources", among which "recovery expenditure due to natural disasters" mainly includes meteorological geological disaster management, comprehensive fire control in key areas and forest pest and disease control; environmental liabilities include "expenditures for returning farmland to forests", "compensation expenditures for ecological benefit", "project expenditures for natural forest protection", "expenditures for forest maintenance" and "other expenditures for environmental liabilities".

3) Net assets account setting of forest resource assets appraisal

The traditional balance sheet follows the relationship of "asset = liability + equity", in which the equity is a reflection of the remaining assets owned or controlled by the owner, that is the net assets. Since the government's initial capital investment and retained earnings of forest resources cannot be directly calculated, only the indirect method of "assets minus liabilities" can be used to obtain the third element. Therefore, it is more reasonable to name the third element with "net resources of forest resources". The meaning of this net assets is to let the manager clearly see the net value of forest resources after deducting annual recovery costs, which reflects the final control quantity of the government's total forest resources owned by the country or region. Its changing trend can have an intuitive reflection and contrast during continuous tabulation. Since the net assets account of forest resources reflect the ownership of forest resources or the ownership of management rights, this item is divided into four categories, i.e., state-owned, collective, individual and other.

According to the above analysis, accounts of the forest resource assets appraisal set up in this work are shown in Table I below.

TABLE I. ASSETS APPRAISAL ACCOUNTS OF FOREST RESOURCES

\begin{tabular}{|c|c|c|}
\hline $\begin{array}{l}\text { Assets appraisal accounts types of forest } \\
\text { resources }\end{array}$ & Level 1 items & Level 2 items \\
\hline \multirow{10}{*}{ Asset account } & \multirow{3}{*}{ Woodland resource account } & Timber woodland \\
\hline & & Economic woodland \\
\hline & & Shelter woodland \\
\hline & \multirow{2}{*}{ Timber resource account } & Artificial forest \\
\hline & & Natural forest \\
\hline & \multirow{5}{*}{$\begin{array}{l}\text { Forest ecological service function } \\
\text { account }\end{array}$} & Water conservation \\
\hline & & Soil conservation \\
\hline & & Carbon fixation and oxygen release \\
\hline & & Air purification \\
\hline & & Biodiversity protection \\
\hline \multirow{8}{*}{ Liability account } & \multirow{3}{*}{ Resource liability } & $\begin{array}{c}\text { Recovery expenditure due to over-quota logging and } \\
\text { deforestation }\end{array}$ \\
\hline & & Recovery expenditure due to natural disasters \\
\hline & & Liability expenditure for other resources \\
\hline & \multirow{5}{*}{ Environmental liability } & Expenditures for returning farmland to forests \\
\hline & & Compensation expenditures for ecological benefit \\
\hline & & Project expenditures for natural forest protection \\
\hline & & Expenditures for forest maintenance \\
\hline & & Other expenditures for environmental liabilities \\
\hline \multirow{4}{*}{ Net assets account } & State-owned forest resources & \\
\hline & Collective forest resources & \\
\hline & Individual forest resources & \\
\hline & Other forest resources & \\
\hline
\end{tabular}

Different resources have different value appraisal methods. For tangible resources, market value method, market inverse algorithm, replacement cost method, and income present value method can be used to evaluate the value of assets. For intangible resources, alternative value method, carbon tax law, opportunity cost method and expense expenditure method can be used indirectly. The value of other resources independent of the current exploitation and utilization of forest resources can be appraised by the method of conditional value.

\section{OfF-OfFICE Audit of Forest Resource Assets}

At present, experts and scholars at home and abroad have not formed a unified view on the meaning of the off-office audit of forest resource assets. The main points are: from the 
perspective of audit purpose, it is mainly to evaluate the performance of leading cadres fulfilling their responsibilities of forest resource asset management during their tenure; from the perspective of auditing content, it is mainly to supervise the authenticity and legitimacy of use and protection of natural resource assets by leading cadres during their term of tenure; from the perspective of audit work, it is mainly to review, attest and evaluate the performance of leading cadres developing, utilizing and protecting forest resource asserts during their tenure, etc. Although different experts and scholars have different views, they are all evaluating the authenticity, legitimacy, and efficiency of leading cadres' management activities such as the development and utilization of forest resource assets during their tenure, auditing the effectiveness of the forest resource asset management system, scientificity of policy making, compliance of policy implementation and effectiveness of policy implementation, and revealing major problems and responsibilities. Based on this, this work analyzed the off-office audit of forest resource assets from the aspects of the target, entity, object, content and index system.

\section{A. The off-office audit target of forest resource assets}

Determining the off-office audit target of forest resource assets needs to combine the national audit target with the strategic deployment on speeding up the construction of ecological civilization made by the Decisions of the Central Committee of the Communist Party of China on Some Major Issues Concerning Comprehensively Deepening the Reform. ${ }^{8,9]}$ In view of this, this work divided the off-office audit target of forest resource assets into three levels, i.e., fundamental target, realistic target and direct goal. The fundamental target is to promote leading cadres to establish a correct concept of political achievements and green development, safeguard national resource security, and safeguard the fundamental interests of the public. The realistic target is to promote the level of administrative management based on laws, to deepen the reform of resources and environmental systems, to promote the improvement of ecological environment, to better maintain the ecological environment and to improve people's livelihood. The direct target is to examine and evaluate the responsibility performance of leading cadres in the development, utilization and supervision of forest resource assets, and define the responsibility for forest resource asset management that should be undertaken.

\section{B. The off-office audit entity of forest resource assets}

From the perspective of principal-agent concept, accountability concept, and audit governance concept, it can be known that [10] the off-office audit entity of forest resource assets should be the national audit institutions. However, in view of the fact that the development and utilization of forest resource assets will affect the construction of ecological civilization and the public, functional departments such as the ministry of forest, the ministry of environmental protection, and the ministry of natural resources can be involved in the audit process. Therefore, the audit entity should achieve full coverage under the leadership of the audit institutions and assist by internal audit and social audit.

\section{The off-office audit object of forest resource assets}

Under the current property rights system, forest resource assets become a public good. Governments at all levels should not only use public means to regulate externality problems in order to ensure fairness in the allocation of forest resources, but also perform accountability, exercise ownership of forest resource assets, and provide public goods in order to ensure the necessary social and public needs for forest resource assets. However, due to the displacement and absence of government functions and the negative behavior of some leading cadres, forest resource assets cannot be reasonably developed and utilized, and even be destroyed. Therefore, the off-office audit object of forest resource assets should be leading cadres at all levels and those in other departments related to forest resource assets management.

\section{The off-office audit content of forest resource assets}

According to the main audit content of the Off-office Audit Regulations of Leading Cadres for Natural Resource Assets (Trial), this work proposed the following contents: first, the implementation performance and effect of laws and regulations as well as policies and measures related to forest resource assets management and ecological environment protection; second, the major decision-making performance of forest resource assets management and ecological environment protection; third, the objectives situation of forest resource assets management and ecological environment protection; fourth, the supervision responsibility of forest resource assets management and ecological environment protection; fifth, the collection and management of funds as well as the construction and operation of major projects related to forest resource assets management and ecological environment protection.

\section{E. The index system of off-office audit of forest resource assets}

In view of the fact that the index system of off-office audit of forest resource assets is still in the exploratory stage, this work attempted to draw on the research results of Cai Chun and Bi Mingyue (2014), He Weiqi and Zhang Yan (2017) based on the Off-office Audit Regulations of Leading Cadres for Natural Resource Assets (Trial) [11, 12], combined with the content proposed above, and constructed a set of index evaluation system in line with local conditions, which is conducive to the continuous protection and utilization of regional forest resource assets.

First, the system and implementation of forest resource assets policies. This index mainly examines the scientific and rational nature of forest resources asset policies, such as whether it conforms to objective laws and whether it can promote the development and protection of forest resources and sustainable economic development. Based on this, three indexes, i.e., the improvement rate of forest resource policies, science rate of forest resource policies and execution rate of forest resource policies.

Second, the major decision-making performance of forest resource assets management and protection. This index mainly reveals the major decision-making deployments, including the decision-making and implementation of major issues related to forest resource assets, the construction of important projects 
related to forest resource assets, the use of large-scale funds related to forest resource assets, and the supervision related to forest resource assets.

Third, the use and performance of forest resource assets funds. This index mainly monitors the legal compliance of funds and sets budget completion rate, capital availability rate, capital use compliance rate, satisfaction extent of forestry ecological engineering construction, satisfaction extent of social work, and the proportion of forestry output to GDP.

Fourth, the management and supervision responsibility for forest resource assets. This index mainly reflects the management and supervision of forest resource assets in terms of quantity and quality. Indexes include forest stock volume, wooded land stock volume, forest cover rate, pest hazard rate, pollution-free rate, forest fire incidence rate, forest fire damage rate and wetland protection rate.

Fifth, the management and protection objectives completion of forest resource assets. In order to supervise the management and protection of forest resource assets, three indexes including the newly-added desertification land management area, the annual harvesting quota implementation rate and the annual afforestation task completion rate are set.

According to the above analysis, the index system and its connotation of the off-office audit of forest resource assets constructed in this work are shown in Table II below.

TABLE II. EVAluation IndeX System OF OFF-OFFICE Audit OF Forest Resource Assets

\begin{tabular}{|c|c|c|c|}
\hline Level 1 index & Level 2 index & Level 3 index & Connotation of calculation methods \\
\hline \multirow{24}{*}{$\begin{array}{l}\text { Evaluation index system of } \\
\text { off-office audit of forest } \\
\text { resource assets }\end{array}$} & \multirow{3}{*}{$\begin{array}{l}\text { System and implementation of } \\
\text { forest resource asset policies }\end{array}$} & $\begin{array}{l}\text { Forest resource policy } \\
\text { improvement rate }\end{array}$ & $\begin{array}{c}\text { The improvement situation of the forest resource } \\
\text { management system }\end{array}$ \\
\hline & & Forest resource policy science rate & Whether the policy is in line with the actual situation \\
\hline & & $\begin{array}{c}\text { Forest resource policy } \\
\text { implementation rate }\end{array}$ & Implementation of forest resources policy \\
\hline & \multirow{4}{*}{$\begin{array}{l}\text { Major decision-making on } \\
\text { management and protection of } \\
\text { forest resource assets }\end{array}$} & $\begin{array}{c}\text { Decision-making and } \\
\text { implementation of major issues in } \\
\text { forest resource assets } \\
\end{array}$ & $\begin{array}{c}\text { Whether to implement major decision-making } \\
\text { procedures for public policy, system, and project } \\
\text { development of forest resource assets }\end{array}$ \\
\hline & & $\begin{array}{l}\text { Construction of important projects } \\
\text { of forest resources assets }\end{array}$ & $\begin{array}{l}\text { Completion of planning objectives for major forest } \\
\text { resources environmental protection projects and } \\
\text { construction of related supporting facilities }\end{array}$ \\
\hline & & $\begin{array}{l}\text { Use of a large amount of funds for } \\
\text { forest resource assets }\end{array}$ & $\begin{array}{l}\text { Use of funds for major environmental protection } \\
\text { projects }\end{array}$ \\
\hline & & $\begin{array}{l}\text { Implementation of forest resource } \\
\text { asset supervision } \\
\end{array}$ & $\begin{array}{l}\text { Reflecting the implementation of forest resource } \\
\text { assets supervision }\end{array}$ \\
\hline & \multirow{6}{*}{$\begin{array}{l}\text { Use and performance of forest } \\
\text { resource asset funds }\end{array}$} & Budget completion rate & Actual completions / budgets*100\% \\
\hline & & Fund availability rate & Actual input / planned investment amount $* 100 \%$ \\
\hline & & Capital use compliance rate & 1- (violation amount / project approval total)*100\% \\
\hline & & $\begin{array}{l}\text { Forestry ecological engineering } \\
\text { construction satisfaction rate }\end{array}$ & $\begin{array}{c}\text { Public satisfaction with forestry ecological } \\
\text { engineering construction / total number of } \\
\text { questionnaires } * 100 \%\end{array}$ \\
\hline & & Social job satisfaction rate & $\begin{array}{l}\text { Public satisfaction with the use of special funds for } \\
\text { natural resources / total number of questionnaires * } \\
100 \%\end{array}$ \\
\hline & & $\begin{array}{l}\text { Proportion of forestry output value } \\
\text { to GDP }\end{array}$ & Forestry output value / GDP total * 100\% \\
\hline & \multirow{8}{*}{$\begin{array}{l}\text { Forest resource asset management } \\
\text { and supervision responsibility }\end{array}$} & Forest stock volume & $\begin{array}{c}\text { Total volume of the trunk portion of the forest that } \\
\text { exists on the forest area / total population of the } \\
\text { region }\end{array}$ \\
\hline & & Forest keeping volume & Land area of growing trees \\
\hline & & Forest cover rate & Forest area / total land area $* 100 \%$ \\
\hline & & Pest hazard rate & Pest hazard area / total area* $100 \%$ \\
\hline & & Pollution-free rate & Pollution-free area / total area*100\% \\
\hline & & Forest fire incidence rate & Number of forest fires / forest area*100\% \\
\hline & & Forest fire damage rate & Affected forest area / total forest area $* 100 \%$ \\
\hline & & Wetland protection rate & Reflecting the protection of forest resources* $100 \%$ \\
\hline & \multirow{3}{*}{$\begin{array}{l}\text { Completion of forest resource asset } \\
\text { management and protection } \\
\text { objectives }\end{array}$} & $\begin{array}{c}\text { Newly-added desertification land } \\
\text { management area }\end{array}$ & $\begin{array}{l}\text { Newly-added desertification land management area } \\
\text { within a certain period of time }\end{array}$ \\
\hline & & $\begin{array}{l}\text { Annual harvesting quota execution } \\
\text { rate }\end{array}$ & Forest harvesting quota completion rate \\
\hline & & $\begin{array}{l}\text { Annual afforestation task } \\
\text { completion rate }\end{array}$ & $\begin{array}{l}\text { The ratio of the actual returning rate to the target } \\
\text { returning forest rate, reflecting the protection of forest } \\
\text { resources }\end{array}$ \\
\hline
\end{tabular}

It can be seen from Table II that the index system consists of qualitative indexes and quantitative indexes. Therefore, different methods can be used to evaluate different indexes, and the weights of each index can be determined by using the
Delphi method, analytic hierarchy method, entropy weight method and principal component analysis method. The calculated results can be taken as the basis for the off-office audit of leading cadres. 


\section{IMPROVING POLICY RECOMMENDATIONS FOR FOREST RESOURCE ASSETS APPRAISAL AND OFF-OFFICE AUDIT}

At present, the research and pilot projects for forest resource assets appraisal and off-office audit are short-lived in theory and practice, and there is no systematic theory. The pilot work is still in the exploratory stage, and the information management of forest resource assets is not perfect enough. A unified and standardized forest balance sheet has not yet been formed, and a lifelong accountability system has not yet been implemented. There is also a lack of a professional talents team for forest resource asset appraisal and auditing. Based on this, this work proposed recommendations to improve the forest resource asset appraisal and off-office audit from the following aspects.

\section{A. Comprehensively carrying out pilot work of forest resource assets appraisal}

Forest resource assets appraisal and off-office audit are still in the exploratory stage, which lacks experience, sufficient audit supervision and management system. Therefore, it is necessary to actively promote forest resource assets appraisal and off-office audit, to comprehensively carry out pilot work, to combine with economic responsibility audit based on summarizing the pilot experience and to continuously innovate audit content and methods, so as to improve audit quality and improve system construction and basic management of ecological civilization. The specific work is as follows:

First, pilot work should be continuously improved. It is necessary to actively exert the enthusiasm of auditors, conduct basic research on the pilot work, summarize the pilot work experience and establish a set of programs that can be widely promoted. Second, pilot work experience exchange should be carried out actively. It is necessary to establish a working experience exchange mechanism among pilot provinces, cities and counties (districts), so as to improve working methods and promote together. Third, economic responsibility off-office audit should be combined to conduct joint audits. Leading cadres can integrate audit resources to overcome the shortage of audit power, promote the full coverage of audit, and conduct a more objective evaluation of forest resource assets.

\section{B. Establishing and improving the information management system of forest resource assets}

Collecting forest resource data information is the basis for carrying out forest resource assets appraisal and off-office audit, and is the foundation to ensure the correctness of data. First, channels for collecting forest resources information should be expanded. Several methods such as scene investigation, auxiliary investigation equipment and research can be used to collect information of forest resource assets, i.e., the current situation, development trends and scientific research results, so as to ensure the integrity and authenticity of the information. Second, a shared center for forest resource asset information should be established. By integrating data network resources, scattered information of forest resource assets can be aggregated. Using Internet technology and big data can analyze resource information, update information resources in real-time and provide information for auditors, which can improve work efficiency and ensure fair and objective appraisal audit. Third, the Forestry Bureau, the Statistics Bureau and other departments should be linked all together. The off-office audit of forest resource assets involves not only the forestry sector but also the relevant departments such as the statistical sector and the agricultural sector. A linkage mechanism should be established for these departments to achieve resource sharing and ensure the objectivity of the audit. Fourth, the Internet audit mode should be actively used. Establishing Internet audit, using big data technology and constructing early warning mechanism of Internet forest resources audit can monitor changes in forest resource assets in real-time to ensure the authenticity of the information.

\section{Compiling a scientific and standardized balance sheet of forest resources}

Although China has not yet formed a unified, scientific and standardized balance sheet of forest resources, forest resource assets and liabilities should be objectively recorded and measured based on requirements of accounting equations in the preparation of the balance sheet. The consumption extent of forest resource assets and the construction and destruction extent of ecological environment during the tenure of leading cadres mainly include the amount of assets, consumption and stock, the extent of damage, and the situation of ecological environment construction and destruction. All of these will be considered to evaluate the consumption extent of forest resource assets and the construction and destruction extent of the ecological environment during the tenure of leading cadres. Meanwhile, principles of "physical accounting before value accounting, tangible assets before intangible assets, and stock assets before flowing assets" should be followed. Appraisal methods and standards for forest resource assets should be studied and summarized deeply combining with the pilot experience. Guided by the national audit institutions and assisted by relevant functional departments such as the Ministry of Agriculture, the Ministry of Environmental Protection, the Ministry of Forestry and the Ministry of Statistics, the balance sheet of forest resource assets can be compiled scientifically.

\section{Establishing and improving the lifelong accountability system of forest resource assets}

Implementing off-office audit of forest resource assets is mainly aimed at promoting the responsibility of leading cadres to earnestly perform forest resource assets management and ecological environmental protection. For those leading cadres who do not perform their duties well, accountability system should be implemented and rectification measures should be formulated to ensure the scientific and rational utilization of audit results. In specific application, the "environmental accountability tracking card" can be adopted, which records in detail major project plans and major decisions, development, utilization and protection of forest resource assets, and environmental construction measures made by each leading cadre during their tenure. Through this kind of tracking card, leading cadres can be evaluated at any time for their performance in terms of various indicators of forest resources assets. It also acts an important reference to track records of off-office audit for leading cadres, which will be included in the integrity archives. 


\section{E. Strengthening the construction of professional talents team for forest resource assets appraisal}

First, it is necessary to integrate audit resources. Due to the wide distribution of forest resource assets, value measurement methods are not uniform, and some important data are scattered among various functional departments. Therefore, when conducting off-office audit, it is necessary to integrate audit resources. Second, it is necessary to expand audit power. The off-office audit of forest resource assets is a brand-new field involving a wide range of knowledge such as auditing, forestry, and environment. It requires a wide range of experts to participate in the audit work. Experts from industry of environment, agriculture, forestry and statistics can be hired to participate in the off-office audit of forest resource assets, which can supplement the audit power and improve the quality of audit. Third, it is necessary to strengthen the training of auditors. Conducting auditor training on a regular or irregular basis can supplement knowledge and skills in a timely manner and improve the professional skills of auditors. Fourth, it is necessary to strengthen the adjustment and construction of disciplines in colleges and universities. In colleges and universities, professional courses or directions such as resource audit, forestry audit and resource accounting can be provided to train a group of audit personnel with professional skills in environmental science engineering. Combined with simulation laboratories and case teaching, they can provide support for the off-office audit of forest resource assets.

\section{CONCLUSIONS}

Based on the current situation of forest resource assets management, this work started with the forest resource assets appraisal, put forward principles, accounts setting and appraisal methods, and constructed a complete off-office audit index system of forest resource assets appraisal. Particularly, it studied deeply the accounts setting of forest resource assets appraisal and off-office audit indexes of forest resource assets appraisal and proposed to set up assets account, liability account and net assets account. It also divided the off-office audit indexes of forest resource assets appraisal into 5 level 2 indexes about policy and implementation and 24 level 3 indexes about policy improvement rate, further improving the theoretical basis of forest resource assets appraisal and off-office audit. In addition, this work proposed suggestions for problems existing in the current forest asset appraisal and off-office audit, i.e., carrying out comprehensive pilot project for the off-office audit of forest resource assets, establishing and improving the forestry resource asset information management system, compiling a scientific and standardized forest resource balance sheet, improving the system of lifelong accountability for forest resource assets and strengthening the construction of professional talents team for forest resource assets appraisal, which can provide practical reference for improving forest resource assets appraisal and off-office audit.

Certainly, there are still some limitations in this work, which need to be further explored and studied. First, improving the accounts setting of forest resource assets. This work followed principles of "assets = liabilities + equity" to divided the forest resource accounts into assets, liabilities and net assets based on the Forestry Industry Standards of People's Republic of China and relevant scholars' research, while in the actual application, the settings of each type of account should be further improved. Second, improving the calculation methods of forest resource assets appraisal account. Although different resources have different methods to appraise values, the basic statistical technique of forest resource assets appraisal is not mature. Therefore, it is impossible to provide data required for calculating various accounts accurately, which needs to be studied deeply in the future. Third, improving the off-office index system of forest resource assets. This work proposed specific contents based on the regulations of the Off-office Audit Regulations of Leading Cadres for Natural Resource Assets (Trial) and research results of predecessors. In actual application, an index system that is more in line with local actual conditions can be established according to the status of forest resource assets in different regions, which can improve the applicability and effectiveness of the index system.

\section{ACKNOWLEDGMENT}

The authors are grateful for the following supports: 2018 Education Research Project of Young and Middle-aged Teachers in Fujian Province (JAS180566); 2014 Scientific Research Youth Talent training Project of Fujian Jiangxia University (2014B002); Special Subject Project for Capital Rating, School of Accounting, Fujian Jiangxia University (JXY201801-15).

\section{REFERENCES}

[1] Wei Yuanzhu, Ren Hengqi, Zhang Chunxia. Reflections on Several Issues Concerning the Management of Forest Resource Assets [J]. Forestry Economics, 2001(10): 22-26.

[2] Mi Mingfu, Wang Qi, Ye Youhua et al. Research on the Framework System of Forest Resources Balance Sheet of State-owned Forest Farms - Taking Guangdong Province as An Example[J]. Forestry Economics, 2018(1): 36-42.

[3] Bai Lianyu. Discussion on the Theoretical Basis of the Forest Resource Balance Sheet Compilation[J]. Green Finance and Accounting, 2015 (10): 3-9.

[4] Wang Xiaoxiao. Development of Forest Resources Balance Sheet of State-owned Forest Farms in Hunan Province [D]. Central South University of Forestry and Technology, 2016.

[5] Huang Rongbing. Research on the Compilation and Audit of Natural Resources Balance Sheet [J]. Audit Research, 2014(1): 37-43.

[6] Wang Xiaoxiao. The Basic Structure of the Forest Resources Balance Sheet [J]. China Forestry Industry, 2017 (2): 211-215.

[7] Mi Mingfu, Wang Qi, Ye Youhua et al. Research on the Framework System of Forest Resources Balance Sheet of State-owned Forest Farms - Taking Guangdong Province as An Example[J]. Forestry Economics, 2018(1): 36-42.

[8] Chen Xiandong. Research on Conducting the Off-office Audit of Natural Resources Assets of Leading Cadres [J]. Audit Research, 2014(5): 15-19

[9] Liu Jiayi. Research on Socialist Auditing Theory with Chinese Characteristics [M]. Beijing: China Economic Publishing House, 2013: 105-110

[10] Su Huishui. Impact of Government Audit on State-owned Enterprise Governance and Asset Preservation and Value-added - Based on the New Perspective of Audit "Governance View"[J]. Journal of Fujian Jiangxia University, 2019(2): 21-32

[11] He Weiqi, Zhang Yan. Research on the Evaluation Index of Off-office Audit of Forest Resources of Leading Cadres [J]. Forestry Economics, 2017 (3): 78-82

[12] Cai Chun, Bi Mingyue. Theoretical Thinking on the Off-office Audit of Natural Resource Assets [J]. Audit Research, 2014(5): 3-9 